\title{
Validity and reliability of the Korean version of the Quality of Recovery-40 questionnaire
}

\author{
Jun Ho Lee, Deokkyu Kim, Donghak Seo, Ji-seon Son, and Dong-Chan Kim \\ Department of Anesthesiology and Pain Medicine, Chonbuk National University Medical School and Hospital, \\ Jeonju, Korea
}

Background: The Quality of Recovery-40 (QoR-40) is a widely-used, self-rated, and self-completed questionnaire for postoperative patients. The questionnaire is intended to elicit information from each patient regarding the quality of recovery during the postoperative period. It is noteworthy, however, that an official Korean version of the QoR-40 (QoR$40 \mathrm{~K}$ ) has not been established. The purpose of this study was to develop the QoR-40K by translation and cultural adaptation process and to evaluate the validity and reliability of the QoR-40K.

Methods: After pre-authorization from the original author of the QoR-40, the translation procedure was established and carried out based upon Beaton's recommendation to create a QoR-40K model comparable to the original English QoR40. Two hundred surgical patients were enrolled, and each completed the questionnaire during the preoperative period, on the third day, and 1 month after surgery. The QoR-40K was compared with the visual analogue scale (VAS) and another health-related questionnaire, the Short-form Health Survery-36 (SF-36). The method of validation for QoR-40K included test-retest reliability, internal consistency, and level of responsiveness.

Results: Spearman's correlation coefficient for test-retest reliability was $0.895(\mathrm{P}<0.001)$, and Cronbach's alpha of the global QoR-40K on the third day after surgery was 0.956 . A positive correlation was obtained between the QoR-40K and the mental component summary of SF-36 $(\rho=0.474, \mathrm{P}<0.001)$, and a negative correlation was observed between QoR$40 \mathrm{~K}$ and VAS $(\rho=-0.341, \mathrm{P}<0.001)$. The standardized responsive mean of the total QoR-40K was 0.71 .

Conclusions: The QoR-40K was found to be as acceptable and reliable as the original English QoR-40 for Korean patients after surgery, despite the apparent differences in the respective patients' cultural backgrounds.

Keywords: Cross-cultural comparison; Korean; Postoperative recovery; Quality of life; Questionnaire.

Corresponding author: Dong-Chan Kim, M.D., Ph.D.

Department of Anesthesiology and Pain Medicine, Chonbuk National University Medical School and Hospital, 20 Gunji-ro, Deokjin-gu, Jeonju 54907, Korea

Tel: 82-63-250-1241, Fax: 82-63-250-1240

Email: dckim@chonbuk.ac.kr

ORCID: https://orcid.org/0000-0002-6881-126X

Received: August 4, 2017.

Revised: September 19, 2017.

Accepted: September 27, 2017.

Korean J Anesthesiol 2018 December 71(6): 467-475 https://doi.org/10.4097/kja.d.18.27188

\section{Introduction}

Issues of safety were traditionally considered primary and the most important consideration when assessing the outcome after anesthesia. However, the significance of the quality of life and the quality of recovery after anesthesia has been emphasized recently, as the mortality rate has decreased due to the improvement of techniques of surgery and anesthesia. With the growing interest in quality of recovery, a number of methods of assessing quality of recovery have been attempted in the field of anesthesiology. One of the most commonly used instruments is the Quality of Recovery-40 questionnaire (QoR-40).

The QoR-40 developed by Myles et al. [1] is a widely used

(c) This is an open-access article distributed under the terms of the Creative Commons Attribution Non-Commercial License (http://creativecommons.org/ licenses/by-nc/4.0/), which permits unrestricted non-commercial use, distribution, and reproduction in any medium, provided the original work is properly cited. 
self-rated questionnaire for early postoperative quality of recovery and health status of patients. The questionnaire is composed of 40 items of 5 sub-scales, physical comfort, emotional state, psychological support, physical independence, and pain, and its validity as an assessment tool for quality of recovery has been evaluated in general surgery, neurosurgery, cardiac surgery and knee surgery etc. [2-4]. Also, it has been compared with the previously known method of evaluating health status and quality of life, Short form-36 (SF-36), and shown high levels of validity among patients who had undergone cardiac surgery [3]. In a systemic review, QoR-40 was a sufficiently valid and reliable method of assessing quality of recovery from 9 countries [5].

The QoR-40 has been translated into several languages including Japanese, Turkish, Iranian, and Portuguese and has demonstrated high levels of both validity and reliability for evaluating the quality of recovery [6-9]. However, the official Korean version of the QoR-40 has not been established so far. Although there are several Korean studies that evaluated quality of recovery using their own translated QoR-40 for Korean patients, the official Korean QoR-40 was not validated [10,11]. Lee et al. [11] compared the validity of QoR-40 between the type of anesthesia (total intravenous anesthesia vs. inhaled anesthesia). The authors pointed out a limitation that the QoR-40 was not formally validated.

The purpose of this study is to develop the Korean version of QoR-40 (QoR-40K) by translation and cultural adaptation process [12] and to evaluate the validity and reliability of the QoR$40 \mathrm{~K}$ for Korean patients who receive general anesthesia.

\section{Materials and Methods}

After the approval of the Institutional Review Board of our Hospital, written informed consent was obtained from all patients who participated in this study. Two hundred patients who were admitted for scheduled elective surgery under general anesthesia during the period November 2015 through October 2016 were enrolled in the study. Most of the surgeries were general, orthopedic, gynecologic, and otorhinolaryngologic surgeries. The specific types of surgery and demographic data are described in Table 1.

Fluency in Korean was requisite: it was required that the subjects enrolled be fully capable of reading and writing Korean fluently. As well, each patient had to be admitted to and had to have spent at least the preoperative night in the hospital. The qualified patients remained an inpatient for three days postoperatively. Those who had cognitive impairment, were younger than 18 years or older than 80 years, American Society of Anesthesiologists physical status III or above, or did not understand the Korean language, and/or had any severe underlying medical condition were excluded from the study. Those who had a his- tory of alcohol or other substance abuse or who refused to participate in this study were also disqualified. Of all the subjects, age, gender, educational and marital status, height and weight, anesthesia and surgery time, and duration in recovery room and hospital stay were all carefully documented. The mean anesthesia time was $168.2 \pm 64.6$ minutes and recovery room stay was $76.1 \pm 21.1$ minutes. The duration of hospitalization was $11.0 \pm$ 7.6 days (Table 1 ).

\section{Development of the QoR-40K}

Before the beginning of the present study process, both development of Korean version of the QoR-40 and its validation process were pre-authorized by the original author. The QoR-40 is a self-rated 40 -item questionnaire that is intended to evaluate the pain, physical, and emotional health status of patients after surgery [1]. The questionnaire is comprised of five subscales: physical comfort $(n=12)$, emotional status $(n=9)$, psychological support $(n=7)$, physical independence $(n=5)$ and pain $(n$ $=7$ ). All the items are scored on a five point Likert scale ranging

Table 1. Demographic Data of the Patients and Characteristics of Surgery and Anesthesia

\begin{tabular}{lc}
\hline & Value \\
\hline Age (yr) & $49(19-77)$ \\
Gender & $65(32.5 \%)$ \\
M & $135(67.5 \%)$ \\
F & $146 / 54$ \\
ASA PS I/II & $64.0 \pm 12.0$ \\
Weight (kg) & $160.7 \pm 8.3$ \\
Height (cm) & $24.6 \pm 3.8$ \\
BMI (kg/m ${ }^{2}$ & \\
Education & $21(11 \%)$ \\
Primary & $26(13 \%)$ \\
Secondary & $91(46 \%)$ \\
High school & $62(31 \%)$ \\
College & \\
Marital status & $164(82 \%)$ \\
Married & $12(6 \%)$ \\
Divorced/widowed & $24(12 \%)$ \\
Single & \\
Type or surgery & $121(61 \%)$ \\
General & $40(20 \%)$ \\
Orthopedic & $30(15 \%)$ \\
Gynecologic & $8(4 \%)$ \\
Otorhinolaryngologic & 1 \\
Others & $168.2 \pm 64.6$ \\
Anesthesia time (min) & $128.2 \pm 61.4$ \\
Surgical time (min) & $76.1 \pm 21.1$ \\
Recovery room stay (min) & $11.0 \pm 7.6$ \\
Duration of admission (day) & \\
\hline
\end{tabular}

Values are mean (range), mean $\pm \mathrm{SD}$, or number of patients (\%). ASA PS: American Society of Anesthesiologists Physical Status, BMI: body mass index. 
from 1 to 5 . Depending on the question, the best answers could be 5 or 1 . For the positive questions, the best answers are scored 5 , but they are scored 1 for the negative items. The total score of QoR-40 is given by the summation of all items, and it ranges from 40 to 200 . Higher scores indicate better quality of recovery.

\section{Translation procedure}

The translation procedure was accomplished based upon the Beaton's and Bullinger's recommendation for QoR-40K, which is compatible with the original English version [12]. In the first translation step, two bilingual translators translated the QoR40 into the Korean language. This step is called the forward translation step according to the Beaton's recommendation. One of these translators was aware of the Beaton's recommendation. The project manager of the study then compared the two translations according to the consistency and the adequacy of the meaning accurately conveyed, and the findings were discussed with the translators (with regard to any of the discrepancies identified). Then, a consensus was reached via the discussion. After the consensus was made, the next step, called backward translation step, was preceded. Delete "The step called backward translation step." The step is called backward translation step. An English native speaking medical doctor and a linguistic specialist translated the consensus version into English. The project manager reviewed the backward translated version with the translators. The backward-translated version received confirmation from the original author, in terms of eligibility. The translated version of QoR-40 was revised by an expert committee including psychologist, general surgeon, anesthesiologist, and translators. The committee revised the discrepancies and errors of the version with the project manager and adopted the QoR$40 \mathrm{~K}$. A pilot study was executed for 10 patients, and the QoR$40 \mathrm{~K}$ was finalized without changing the questions.

\section{Protocol}

The final version of the QoR-40K was tested a day before surgery, on the third day after surgery (twice on the same day), and a month after surgery. The pre-operative and post-operative quality of life was also assessed by the SF-36 Korean version 2.0. The SF-36 is also a health related quality of life questionnaire that has been previously validated in Korea [13]. The Korean version of SF-36 consists of 36 items in 8 subscales: physical functioning, role-physical, bodily pain, general health perception, vitality, social functioning, role-emotional, and mental health. All scores of the subscales range from 0 to 100 . Higher score translates to better quality of life at various levels. Those are summarized in two categories: physical component summary and mental component summary.

In a preoperative visit, the patients were asked to test QoR$40 \mathrm{~K}, \mathrm{SF}-36$ Korean v 2.0, and $100 \mathrm{~mm}$ visual analogue scale (VAS) with informed consent. The VAS ranged from 0 to 100 $\mathrm{mm}$, which means pain-free to severe pain. Unlike other previous studies, we evaluated VAS for pain because we postulated that postoperative pain would be the most prominent factor of the quality of recovery in acute phase of recovery. Additional patients' information such as age, gender, height, weight, education level and marital status was gathered. After the operation, the duration of each anesthesia, operation, and recovery room

Table 2. Change in the QoR-40K of Patients a Day before Surgery (Preoperative) and Three Days after Surgery (Postoperative)

\begin{tabular}{|c|c|c|c|c|c|}
\hline Score & Max score & Preoperative & Postoperative & $\%$ Change from baseline & SRM \\
\hline Global QoR-40K & 200 & $168.4 \pm 21.4$ & $151.0 \pm 24.4$ & $10 \%$ & 0.71 \\
\hline Physical comfort & 60 & $52.3 \pm 6.3$ & $47.3 \pm 6.7$ & $9 \%$ & 0.75 \\
\hline Emotional state & 45 & $36.4 \pm 6.2$ & $34.5 \pm 7.4$ & $5 \%$ & 0.26 \\
\hline Psychological support & 35 & $28.7 \pm 5.2$ & $26.8 \pm 5.6$ & $7 \%$ & 0.34 \\
\hline Physical independence & 25 & $19.3 \pm 5.0$ & $14.1 \pm 5.1$ & $27 \%$ & 1.02 \\
\hline Pain & 35 & $31.6 \pm 4.4$ & $28.6 \pm 5.7$ & $9 \%$ & 0.53 \\
\hline
\end{tabular}

QoR-40K: Korean version of Quality of Recovery-40, SRM: standardized response mean (mean change/SD).

Table 3. Inter-dimension Correlation for the QoR-40K

\begin{tabular}{lcccc}
\hline & Global QoR-40K & Physical comfort & Emotional state & Psychological support \\
\hline Physical comfort & 0.899 & - & & - \\
Emotional state & 0.882 & 0.748 & 0.521 & - \\
Psychological support & 0.709 & 0.537 & 0.577 & 0.499 \\
Physical independence & 0.759 & 0.626 & 0.618 & 0.353 \\
Pain & 0.737 & 0.579 & 0.423 \\
\hline
\end{tabular}

Inter-dimension Cronbach $\alpha=0.855$. QoR-40K: Korean version of Quality of Recovery-40. 
stay were documented. On the third day after surgery, the patients were asked to test QoR- $40 \mathrm{~K}$ and $100 \mathrm{~mm}$ VAS. The tests were repeated in the morning and afternoon twice to assess the reliability. At one month postoperative, the patients were asked to test QoR-40K, SF-36 and VAS. The duration of the admission was recorded for every patient (Table 1).

Validity was tested for accuracy of QoR-40K. For convergent validity, the QoR-40K and VAS were compared, and the interdimension correlation was measured. The associations between QoR-40K and duration of the respective admission and recovery

Table 4. QoR-40K Items and Factor Analysis

\begin{tabular}{|c|c|c|c|c|}
\hline & Mean & $\mathrm{SD}$ & Factor loading & Coefficient \\
\hline \multicolumn{5}{|l|}{ Physical comfort $(\alpha=0.902)$} \\
\hline Able to breathe easy & 3.56 & 1.17 & 0.571 & 0.734 \\
\hline Have a good sleep & 3.16 & 1.23 & 0.646 & 0.648 \\
\hline Able to enjoy food & 2.94 & 1.35 & 0.765 & 0.612 \\
\hline Feeling rested & 3.11 & 1.17 & 0.760 & 0.715 \\
\hline Nausea & 4.08 & 1.06 & 0.596 & 0.739 \\
\hline Vomiting & 4.46 & 0.95 & 0.720 & 0.776 \\
\hline Dry retching & 4.34 & 0.98 & 0.744 & 0.809 \\
\hline Feeling restless & 4.45 & 0.87 & 0.654 & 0.658 \\
\hline Shaking & 4.51 & 0.82 & 0.746 & 0.719 \\
\hline Shivering & 4.41 & 0.87 & 0.814 & 0.716 \\
\hline Feeling cold & 4.35 & 0.86 & 0.752 & 0.680 \\
\hline Feeling dizzy & 4.07 & 0.95 & 0.608 & 0.665 \\
\hline \multicolumn{5}{|l|}{ Emotional state $(\alpha=0.907)$} \\
\hline Feeling comfortable & 3.10 & 1.14 & 0.656 & 0.716 \\
\hline General feeling of well-being & 2.96 & 1.20 & 0.719 & 0.663 \\
\hline Feeling in control & 3.31 & 1.12 & 0.558 & 0.739 \\
\hline Bad dreams & 4.36 & 0.96 & 0.512 & 0.740 \\
\hline Feeling anxious & 4.11 & 1.02 & 0.641 & 0.831 \\
\hline Feeling angry & 4.22 & 0.96 & 0.665 & 0.839 \\
\hline Feeling depressed & 4.08 & 0.99 & 0.773 & 0.826 \\
\hline Feeling alone & 4.13 & 1.04 & 0.783 & 0.788 \\
\hline Difficulty falling asleep & 3.87 & 1.13 & 0.693 & 0.722 \\
\hline \multicolumn{5}{|l|}{ Psychologic support ( $\alpha=0.878)$} \\
\hline Able to communicate with hospital staff & 3.61 & 1.15 & 0.699 & 0.759 \\
\hline Able to communicate with family & 3.81 & 1.05 & 0.696 & 0.795 \\
\hline Able to communicate with doctors & 3.79 & 1.09 & 0.868 & 0.860 \\
\hline Able to communicate with nurses & 3.90 & 1.07 & 0.850 & 0.836 \\
\hline Having support from family & 3.83 & 1.05 & 0.820 & 0.829 \\
\hline Able to understand instructions & 3.79 & 0.98 & 0.727 & 0.771 \\
\hline Feeling confused & 4.17 & 0.97 & 0.717 & 0.465 \\
\hline \multicolumn{5}{|l|}{ Physical independence $(\alpha=0.844)$} \\
\hline Able to return to work & 2.08 & 1.35 & 0.520 & 0.639 \\
\hline Able to write & 3.10 & 1.41 & 0.601 & 0.815 \\
\hline Have normal speech & 3.38 & 1.11 & 0.582 & 0.752 \\
\hline Wash, brush teeth, shave & 3.00 & 1.41 & 0.691 & 0.858 \\
\hline Able to look after appearance & 2.53 & 1.30 & 0.695 & 0.863 \\
\hline \multicolumn{5}{|l|}{ Pain $(\alpha=0.889)$} \\
\hline Moderate pain & 3.69 & 1.01 & 0.675 & 0.717 \\
\hline Severe pain & 4.03 & 1.10 & 0.705 & 0.764 \\
\hline Headache & 4.18 & 0.98 & 0.744 & 0.820 \\
\hline Muscle pain & 4.06 & 1.10 & 0.743 & 0.850 \\
\hline Backache & 4.11 & 1.10 & 0.720 & 0.823 \\
\hline Sore throat & 4.13 & 1.09 & 0.657 & 0.783 \\
\hline Sore mouth & 4.37 & 1.03 & 0.503 & 0.671 \\
\hline
\end{tabular}

Consistency is represented with Cronbach $\alpha$, factor loading, and item-to-own dimension correlation coefficients are presented. QoR-40K: Korean version of Quality of Recovery-40. 
room periods were measured for predictive validity. Also, the association between QoR-40K and SF-36 was measured. The assessment of factor analysis was confirmed by Kaiser-MeyerOlkin (KMO) measure of sampling adequacy and Bartlett test of sphericity.

Reliability was measured for consistency of the QoR-40K. The reliability was assessed by internal consistency and testretest reliability, which were tested on the third day after surgery. For test-retest reliability, patients completed the QoR-40K questionnaire in the morning and afternoon twice. For internal consistency, each item of QoR-40K and its own dimension were compared and then the correlation was measured. Those were measured by Cronbach $\alpha$ and interclass coefficient.

Clinical feasibility of the QoR-40K was evaluated with completion rate and recruitment rate. Responsiveness was measured by standardized response mean (SRM), which is acquired by change of mean divided by standard deviation. Factorial analysis was executed to acquire factor loading of each item of the questionnaire.

\section{Statistical analysis}

The data were presented as mean \pm SD. Associations were measured by Spearman's correlation coefficient $(\rho)$ or Cronbach's alpha ( $\alpha$ ). All statistical analyses were performed using SPSS Statistics for Windows, ver. 24.0 (SPSS, IBM Corp., USA). Values were considered statistically significant when $\mathrm{P}<0.05$.

\section{Results}

Of the enrolled 200 patients, 2 patients canceled operation, 2 patients underwent surgery under regional anesthesia, and 11 patients were discharged early (within 3 days of surgery). Of the total, 173 (completion rate: 87\%) patients completed QoR-40K and SF-36 1 month after surgery. The patients who completed all the questionnaires as above were statistically processed for validity and reliability. Most of the patients were able to complete the questionnaire without any difficulty within about 6 minutes.

On postoperative day 3, QoR-40K score was decreased to $151.0 \pm 24.4$ when compared with preoperative QoR-40K score $168.4 \pm 21.4(\mathrm{P}<0.05)$. The QoR-40K score 1 month after surgery was increased to $161.0 \pm 17.8$ compared with postoperative day $3(\mathrm{P}<0.05)$. Changes in preoperative and postoperative QoR-40K and responsiveness are described in Table 2. SRM between preoperative and postoperative QoR-40K was 0.71 , where 0.2 indicated a small, 0.5 a moderate, and 0.8 a large effect of intervention [14].

The QoR-40K and VAS were moderately correlated. The correlation coefficients between the QoR- $40 \mathrm{~K}$ and VAS were -0.236 $(\mathrm{P}=0.002)$ on the day before surgery and $-0.341(\mathrm{P}<0.001)$ on postoperative day 3 . The postoperative absolute value of the correlation coefficient was greater than the preoperative value. The QoR-40K scores were moderately correlated with physical component scale $(\rho=0.449, \mathrm{P}<0.001)$ and mental component scale ( $\rho=0.474, \mathrm{P}<0.001$ ) of SF-36 on postoperative day 3 . The VAS was also found to be moderately correlated with SF-36 (Table 5).

Spearman's correlation coefficient for test-retest reliability was 0.895 and Cronbach a for internal consistency of QoR$40 \mathrm{~K}$ was 0.956 , where the recommended reliable value for these tests is more than 0.7 [15]. The median item-to-own dimension Cronbach $\alpha$ and coefficients for each dimension were: physical comfort ( $\alpha=0.899, \rho=0.716)$, emotional state $(\alpha=0.882, \rho=$ 0.740 ), psychological support ( $\alpha=0.709, \rho=0.795)$, physical independence ( $\alpha=0.759, \rho=0.815)$, and pain $(\alpha=0.737, \rho=$ 0.783 ). The inter-dimension correlation of each dimension is presented in Table 3.

The principal component analysis revealed 5 factor structure as the original English version of the QoR-40 [1]. The KMO value to take the measure of sampling adequacy was 0.903 , and $P$ value of Bartlett's test of sphericity was $<0.001$ so that the assessment of factor analysis was confirmed. The factor loadings of each item are shown in Table 4: physical comfort (0.571$0.814)$, emotional state $(0.512-0.783)$, psychological support (0.696-0.868), physical independence (0.520-0.695), and pain (0.503-0.744).

There was no appreciable difference between the QoR-40K scores of men and women $(151.5 \pm 26.2$ vs. $150.8 \pm 27.0, \mathrm{P}=$ 0.652). For education level, no difference was found among the levels (college 156.2 \pm 21.4 , high school $147.7 \pm 30.7$, secondary $152.6 \pm 17.3$, and primary $150.0 \pm 30.3, \mathrm{P}=0.420$ ). Although the authors expected a significant difference between the QoR-40K and duration of each hospitalization, the stay in recovery room and anesthesia time, no statistically significant difference was observed.

Table 5. The Spearman Correlation between QoR-40K and SF-36 Scores

\begin{tabular}{|c|c|c|c|c|c|}
\hline & & \multicolumn{4}{|c|}{ SF-36 } \\
\hline & & \multicolumn{2}{|c|}{ PCS } & \multicolumn{2}{|c|}{ MCS } \\
\hline & & $\rho$ & $\mathrm{P}$ & $\rho$ & $\mathrm{P}$ \\
\hline \multirow[t]{6}{*}{ QoR-40K } & Physical comfort & 0.401 & $<0.001$ & 0.464 & $<0.001$ \\
\hline & Emotional state & 0.326 & $<0.001$ & 0.430 & $<0.001$ \\
\hline & Psychological support & 0.200 & 0.008 & 0.171 & 0.025 \\
\hline & Physical independence & 0.360 & $<0.001$ & 0.379 & $<0.001$ \\
\hline & Pain & 0.424 & $<0.001$ & 0.347 & $<0.001$ \\
\hline & Global QoR-40K & 0.449 & $<0.001$ & 0.474 & $<0.001$ \\
\hline
\end{tabular}

QoR-40K: Korean version of Quality of Recovery-40, SF-36: Short Form health survey Korean version 2.0, PCS: physical component scale, MCS: mental component scale. 


\section{Discussion}

In the present study, the QoR-40K was developed by cross-cultural translation and its validity, reliability and acceptability were evaluated. The overall result of this study indicates that the QoR-40K is an acceptable method of assessing quality of recovery in the aspects of validity, reliability, and feasibility after general anesthesia for Korean patients, although the cultural background is different from the English speaking countries.

Most patients were able to complete the questionnaire without appreciable difficulty in approximately 6 minutes. This indicates that the QoR-40K has a fairly acceptable feasibility of successfully completing the answer to the questionnaire. The relationships between the VAS and the SF-36 and the QoR-40K were statistically well-correlated. This indicates that QoR-40K has meaningful convergent validity. Inter-dimension correlations were sufficiently strong to permit the conclusion that the QoR-40K has an acceptable level of validity, also it well supports the construct validity. In this study, the factor analysis was also conducted as a method of validation and confirmed by KMO measurement and Barlett's test. As a result of our study, most of the items of the QoR-40K have validity by factor analysis.

The results of test-retest reliability and internal consistency of the QoR-40K indicated that QoR-40K has an acceptable level of reliability. For the test-retest the value of Cronbach a was 0.956 , which exceeds the established criterion for good reliability, 0.7. Also, internal consistency was measured by median correlation between items within each dimension. As our results those values were high enough to allow the conclusion that the QoR-40K has sufficient reliability. Concurrent validity comes from the relationship between the VAS and the QoR-40K. Therefore, QoR$40 \mathrm{~K}$ can be considered as a reliable questionnaire.

The SRM of the overall QoR-40K was 0.71, which translates moderate capacity to detect change. The SRM of the emotional state was relatively lower than the original version of the QoR40 , as well as other previous studies [1,6-8]. The lower SRM may be the result of the different administration time of the QoR-40K, which was done on postoperative day 3 (as was done in our study). Emotional state may be recovered earlier than other subscales of the QoR- $40 \mathrm{~K}$ compared with the original QoR-40 study. In addition, the SRM of emotional state was lower than other subscales in a study of the Japanese version of the QoR-40 as in our study [6]. Japan is an East Asian country, and the Japanese people share many common cultural attributes and customs with the people of Korea. Thus, it would be reasonable to anticipate that some of the mental and emotional features of the Korean and Japanese patients would be quite similar.

In the previous studies, anesthesia and operation time, recovery room stay, and the duration of the overall hospitalization were found to bear relationships with the QoR-40 scores. However, those correlations with QoR-40K were not found to be statistically significant in this study. The result may be attributable to the evaluating time difference of the postoperative QoR-40K. Also, various other factors such as patient-related, operation-related, or Korean medical system-related circumstance may affect our result, and further study regarding those factors would be required.

There is a limitation in the present study. This study evaluated the patients recovering from general, orthopedic, gynecologic, and otorhinolaryngologic surgeries. Therefore, the result of the study may be constrained when it comes to generalizing the results to the general population. However, other validation studies generalized the quality of recovery with some parts of surgery group. Despite the above limitation, this study is the first validation of the Korean version of the QoR-40. Although this is not an optimal study and improvement is always possible, the authors are confident that more studies will be facilitated involving the QoR-40K.

In conclusion, the Korean version of QoR-40 has acceptable validity, reliability, and feasibility to assess the quality of recovery after general anesthesia in spite of cultural differences. It is expected that the QoR-40K will be a useful tool to evaluate the quality of recovery for Korean surgical patients in the future.

\section{Acknowledgments}

We thank Dr. Paul Myles for allowing us to translate the QoR-40 into Korean and to utilize the questionnaire.

\section{ORCID}

Jun Ho Lee, https://orcid.org/0000-0002-9424-8589

Deokkyu Kim, https://orcid.org/0000-0001-7613-3529

Ji-seon Son, https://orcid.org/0000-0002-6672-4576

Dong-Chan Kim, https://orcid.org/0000-0002-6881-126X

\section{References}

1. Myles PS, Weitkamp B, Jones K, Melick J, Hensen S. Validity and reliability of a postoperative quality of recovery score: the QoR-40. Br J Anaesth 2000; 84: 11-5.

2. Leslie K, Troedel S, Irwin K, Pearce F, Ugoni A, Gillies R, et al. Quality of recovery from anesthesia in neurosurgical patients. Anesthesiology 
2003; 99: 1158-65.

3. Myles PS, Hunt JO, Fletcher H, Solly R, Woodward D, Kelly S. Relation between quality of recovery in hospital and quality of life at 3 months after cardiac surgery. Anesthesiology 2001; 95: 862-7.

4. Yadeau JT, Goytizolo EA, Padgett DE, Liu SS, Mayman DJ, Ranawat AS, et al. Analgesia after total knee replacement: local infiltration versus epidural combined with a femoral nerve blockade: a prospective, randomised pragmatic trial. Bone Joint J 2013; 95: 629-35.

5. Gornall BF, Myles PS, Smith CL, Burke JA, Leslie K, Pereira MJ, et al. Measurement of quality of recovery using the QoR-40: a quantitative systematic review. Br J Anaesth 2013; 111: 161-9.

6. Tanaka Y, Wakita T, Fukuhara S, Nishiwada M, Inoue S, Kawaguchi M, et al. Validation of the Japanese version of the quality of recovery score QoR-40. J Anesth 2011; 25: 509-15.

7. Karaman S, Arici S, Dogru S, Karaman T, Tapar H, Kaya Z, et al. Validation of the Turkish version of the Quality of Recovery-40 questionnaire. Health Qual Life Outcomes 2014; $12: 8$.

8. Yaghoobi S, Hamidfar M, Lawson DM, Fridlund B, Myles PS, Pakpour AH. Validity and reliability of the Iranian version of the quality of recovery-40 questionnaire. Anesth Pain Med 2015; 5: e20350.

9. Eduardo AH, Santos CB, Carvalho AM, Carvalho EC. Validação da versão brasileira do questionário Quality of Recovery-40 Items. Acta Paul Enferm 2016; 29: 253-9.

10. Hong SH, Lee JM, Park CM, Park HJ, Jeon JP, Yu MR, et al. Assessment for the quality of recovery from general anesthesia in patients with gynecologic surgery. Korean J Anesthesiol 2008; 54: 531-7.

11. Lee WK, Kim MS, Kang SW, Kim S, Lee JR. Type of anaesthesia and patient quality of recovery: a randomized trial comparing propofolremifentanil total i.v. anaesthesia with desflurane anaesthesia. Br J Anaesth 2015; 114: 663-8.

12. Beaton DE, Bombardier C, Guillemin F, Ferraz MB. Guidelines for the process of cross-cultural adaptation of self-report measures. Spine (Phila Pa 1976) 2000; 25: 3186-91.

13. Kim SH, Jo MW, Lee SI. Psychometric properties of the Korean short form-36 health survey version 2 for assessing the general population. Asian Nurs Res (Korean Soc Nurs Sci) 2013; 7: 61-6.

14. Peterson RA. A meta-analysis of Cronbach's coefficient alpha. J Consum Res 1994; 21: 381-91.

15. McDowell I. Measuring Health: A Guide to Rating Scales and Questionnaires. 3rd ed. Oxford University Press, Inc., Newyork. 2006. 
Appendix. 마취 후 회복 정도 조사 (QoR-40K)

성명 :

연구번호 :

등록번호 :

\section{다음의 문항을 읽고, 해당되는 보기에 표시하십시오.}

\section{[1부. 지난 24시간 동안 느꼈던 감정]}

1. 지난 24시간 동안 편하게 숨을 쉴 수 있었습니까?

(1) 전혀 그렇지 않았다. (2) 가끔 그런 적이 있다.

$\begin{array}{lll}\text { (3) 보통 그랬다. } & \text { (4) 대부분 그랬다. } & \text { (5) 항상 그랬다. }\end{array}$

2. 지난 24 시간 동안 편하게 잠을 잘 수 있었습니까?
(1) 전혀 그렇지 않았다.
(2) 가끔 그런 적이 있다.
(3) 보통 그랬다.
(4) 대부분 그랬다.
(5) 항상 그랬다.

3. 지난 24시간동안 음식을 잘 먹을 수 있었습니까?
(1) 전혀 그렇지 않았다.
(2) 가끔 그런 적이 있다.
(3) 보통 그랬다.
(4) 대부분 그랬다.
(5) 항상 그랬다.

4. 지난 24시간 동안 편안하게 쉴 수 있었습니까?
(1) 전혀 그렇지 않았다.
(2) 가끔 그런 적이 있다.
(3) 보통 그랬다.
(4) 대부분 그랬다.
(5) 항상 그랬다.

5. 지난 24 시간 동안 일반적으로 행복감을 느꼈습니까?
(1) 전혀 그렇지 않았다.
(2) 가끔 그런 적이 있다.
(3) 보통 그랬다.
(4) 대부분 그랬다.
(5) 항상 그랬다.

6. 지난 24시간 동안 감정을 조절할 수 있었습니까?
(1) 전혀 그렇지 않았다.
(2) 가끔 그런 적이 있다.
(3) 보통 그랬다.
(4) 대부분 그랬다.
(5) 항상 그랬다.

7. 지난 24 시간 동안 편안함을 느꼈습니까?
(1) 전혀 그렇지 않았다.
(2) 가끔 그런 적이 있다.
(3) 보통 그랬다.
(4) 대부분 그랬다.
(5) 항상 그랬다.

8. 지난 24시간 동안 평소와 같이 말을 할 수 있었습니까?
(1) 전혀 그렇지 않았다.
(2) 가끔 그런 적이 있다.
(3) 보통 그랬다.
(4) 대부분 그랬다.
(5) 항상 그랬다.

9. 지난 24 시간 동안 평소와 같이 씻고, 양치하고, 면도를 할 수 있었습니까? (1) 전혀 그렇지 않았다. (2) 가끔 그런 적이 있다. (3) 보통 그랬다.
(4) 대부분 그랬다.
(5) 항상 그랬다.

10. 지난 24 시간 동안 평소와 같이 자신의 외모를 가꿀 수 있었습니까?
(1) 전혀 그렇지 않았다.
(2) 가끔 그런 적이 있다.
(3) 보통 그랬다.
(4) 대부분 그랬다.
(5) 항상 그랬다.

11. 지난 24 시간 동안 평소와 같이 글씨를 쓸 수 있었습니까?
(1) 전혀 그렇지 않았다.
(2) 가끔 그런 적이 있다.
(3) 보통 그랬다.
(4) 대부분 그랬다.
(5) 항상 그랬다.

12. 지난 24 시간 동안 일상적인 집안일 또는 직장 일을 할 수 있었습니까?
(1) 전혀 그렇지 않았다.
(2) 가끔 그런 적이 있다.
(3) 보통 그랬다.
(4) 대부분 그랬다.
(5) 항상 그랬다.

13. 지난 24시간 동안 병원 직원과 대화할 수 있었습니까(입원해 있을 경우)?
(1) 전혀 그렇지 않았다.
(2) 가끔 그런 적이 있다.
(3) 보통 그랬다.
(4) 대부분 그랬다.
(5) 항상 그랬다.

14. 지난 24 시간 동안 가족이나 친구들과 평소와 같이 대화할 수 있었습니까?

(1) 전혀 그렇지 않았다.

(2) 가끔 그런 적이 있다.

(3) 보통 그랬다.

(4) 대부분 그랬다.

(5) 항상 그랬다.

15. 지난 24 시간 동안 병원의 의사에게 도움을 받을 수 있었습니까(입원해 있을 경우)?
(1) 전혀 그렇지 않았다.
(2) 가끔 그런 적이 있다.
(3) 보통 그랬다.
(4) 대부분 그랬다.
(5) 항상 그랬다.

16. 지난 24 시간 동안 병원의 간호사에게 도움을 받을 수 있었습니까(입원해 있을 경우)?
(1) 전혀 그렇지 않았다.
(2) 가끔 그런 적이 있다.
(3) 보통 그랬다.
(4) 대부분 그랬다.
(5) 항상 그랬다.

17. 지난 24시간 동안 가족이나 친구들에게 도움을 받을 수 있었습니까?
(1) 전혀 그렇지 않았다.
(2) 가끔 그런 적이 있다.
(3) 보통 그랬다.
(4) 대부분 그랬다.
(5) 항상 그랬다.

18. 지난 24 시간 동안 병원이나 주변에서 제공하는 지침이나 조언을 이해할 수 있었습니까?
(1) 전혀 그렇지 않았다.
(2) 가끔 그런 적이 있다.
(3) 보통 그랬다.
(4) 대부분 그랬다.
(5) 항상 그랬다. 


\section{[2부. 지난 24 시간 동안 발생한 증상]}

19. 지난 24 시간 동안 메스꺼움을 느낀 적이 있습니까?
(1) 항상 그랬다.
(2) 대부분 그랬다.
(3) 보통 그랬다.
(4) 가끔 그런 적이 있다. (5) 전혀 그렇지 않았다.

20. 지난 24 시간 동안 구토를 하였습니까?
(1) 항상 그랬다.
(2) 대부분 그랬다.
(3) 보통 그랬다.
(4) 가끔 그런 적이 있다.
(5) 전혀 그렇지 않았다.

21. 지난 24 시간 동안 헛구역질을 하였습니까?
(1) 항상 그랬다.
(2) 대부분 그랬다.
(3) 보통 그랬다.
(4) 가끔 그런 적이 있다.
(5) 전혀 그렇지 않았다.

22. 지난 24 시간 동안 가만히 있지 못하는 들뜬 기분이 들었습니까?
(1) 항상 그랬다.
(2) 대부분 그랬다.
(3) 보통 그랬다.
(4) 가끔 그런 적이 있다. (5) 전혀 그렇지 않았다.

23. 지난 24 시간 동안 떨림이나 경련이 있었습니까?
(1) 항상 그랬다.
(2) 대부분 그랬다.
(3) 보통 그랬다.
(4) 가끔 그런 적이 있다.
(5) 전혀 그렇지 않았다.

24. 지난 24 시간 동안 추워서 몸이 떨리는 경험을 했습니까?
(1) 항상 그랬다.
(2) 대부분 그랬다.
(3) 보통 그랬다.
(4) 가끔 그런 적이 있다.
(5) 전혀 그렇지 않았다.

25. 지난 24 시간 동안 춥다는 느낌이 들었습니까?
(1) 항상 그랬다.
(2) 대부분 그랬다.
(3) 보통 그랬다.
(4) 가끔 그런 적이 있다. (5) 전혀 그렇지 않았다.

26. 지난 24 시간 동안 어지러움이 있었습니까?
(1) 항상 그랬다.
(2) 대부분 그랬다.
(3) 보통 그랬다.
(4) 가끔 그런 적이 있다.
(5) 전혀 그렇지 않았다.

27. 지난 24 시간 동안 악몽을 꾼 것 같은 느낌이 들었습니까?
(1) 항상 그랬다.
(2) 대부분 그랬다.
(3) 보통 그랬다.
(4) 가끔 그런 적이 있다.
(5) 전혀 그렇지 않았다.

28. 지난 24 시간 동안 불안감이 들었습니까?
(1) 항상 그랬다.
(2) 대부분 그랬다.
(3) 보통 그랬다.
(4) 가끔 그런 적이 있다. (5) 전혀 그렇지 않았다.

29. 지난 24 시간 동안 화가 났습니까?
(1) 항상 그랬다.
(2) 대부분 그랬다.
(3) 보통 그랬다.
(4) 가끔 그런 적이 있다.
(5) 전혀 그렇지 않았다.

30. 지난 24 시간 동안 우울한 기분이 들었습니까?
(1) 항상 그랬다.
(2) 대부분 그랬다.
(3) 보통 그랬다.
(4) 가끔 그런 적이 있다.
(5) 전혀 그렇지 않았다.

31 . 지난 24 시간 동안 홀로 남겨진 듯한 기분이 들었습니까?
(1) 항상 그랬다.
(2) 대부분 그랬다.
(3) 보통 그랬다.
(4) 가끔 그런 적이 있다. (5) 전혀 그렇지 않았다.

32. 지난 24 시간 동안 잠을 이루기 힘들었습니까?

(1) 항상 그랬다.

(2) 대부분 그랬다.

(3) 보통 그랬다.

(4) 가끔 그런 적이 있다. (5) 전혀 그렇지 않았다.

33. 지난 24 시간 동안 혼란스러운 느낌이 들었습니까?
(1) 항상 그랬다.
(2) 대부분 그랬다.

(3) 보통 그랬다.

(4) 가끔 그런 적이 있다.

(5) 전혀 그렇지 않았다.

34 . 지난 24 시간 동안 중간 정도의 통증이 있었습니까?
(1) 항상 그랬다.
(2) 대부분 그랬다.

(3) 보통 그랬다.

(4) 가끔 그런 적이 있다. (5) 전혀 그렇지 않았다.

35. 지난 24 시간 동안 심한 통증이 있었습니까?
(1) 항상 그랬다.

(2) 대부분 그랬다.

(3) 보통 그랬다.

(4) 가끔 그런 적이 있다. (5) 전혀 그렇지 않았다.

36. 지난 24 시간 동안 두통이 있었습니까?
(1) 항상 그랬다.
(2) 대부분 그랬다.
(3) 보통 그랬다.
(4) 가끔 그런 적이 있다. (5) 전혀 그렇지 않았다.

37. 지난 24 시간 동안 근육통이 있었습니까?
(1) 항상 그랬다.
(2) 대부분 그랬다.
(3) 보통 그랬다.
(4) 가끔 그런 적이 있다.
(5) 전혀 그렇지 않았다.

38. 지난 24 시간 동안 허리 통증이 있었습니까?
(1) 항상 그랬다.
(2) 대부분 그랬다.

(3) 보통 그랬다.

(4) 가끔 그런 적이 있다. (5) 전혀 그렇지 않았다.

39. 지난 24 시간 동안 목이 아팠습니까?
(1) 항상 그랬다.
(2) 대부분 그랬다.
(3) 보통 그랬다.
(4) 가끔 그런 적이 있다. (5) 전혀 그렇지 않았다.

40. 지난 24 시간 동안 입안의 염증이 생겼습니까?
(1) 항상 그랬다.
(2) 대부분 그랬다.

(3) 보통 그랬다.

(4) 가끔 그런 적이 있다. (5) 전혀 그렇지 않았다. 